\title{
THE WHEN AND HOW OF CORPORATE VENTURING IN FAMILY FIRMS: A CONCEPTUAL FRAMEWORK
}

\begin{abstract}
The distinctive trait of this study on corporate venturing in family business resides in the focus on the temporal dimension. The three circle model of family business is affected by temporal dynamics, so that entrepreneurial behavior can be depicted as function of the development, and not just the overlap, of the dimensions that characterize a family firm, namely family, ownership and business. By relying on the concept of family business developmental dimensions this study discusses when and how family firms' goals lead to pursuing corporate venturing initiatives. Our framework offers a comprehensive approach to the 'complicating factor of life-cycle' and clarifies family firms propensity for internal rather than external corporate venturing initiatives.
\end{abstract}

\section{Keywords}

Family firms, developmental dimensions, goals, internal corporate venturing, external corporate venturing 


\section{INTRODUCTION}

Corporate entrepreneurship (CE) scholars have recently found great interest for the case of family firms (Nordqvist and Melin, 2010; McKelvie et al., 2013). Family firms are defined as businesses "governed and/or managed with the intention to shape and pursue the vision of the business held by a dominant coalition controlled by members of the same family or a small number of families in a manner that is potentially sustainable across generations of the family or families" (Chua, Chrisman, \& Sharma, 1999, p. 25). Family firms are organizations with distinctive resources, behaviors and strategic preferences (De Massis et al., 2013; Sharma et al. (2014a). Accordingly, a number of theoretical arguments have been advanced as to why the antecedents and consequences of CE are different in family and non-family firms (e.g., unique investment horizons, diversification plans and risk tolerance, firm strategy and distinctive management and governance processes) (Chrisman et al., 2013). At the same time, given their unique concern for sustained regeneration and transgenerational succession, $\mathrm{CE}$ is of particular interest to family firms (Nordqvist \& Melin, 2010; Gomez-Mejia et al., 2011; Zellweger et al., 2012). Overall, family firms represent a particularly rich context for the study of CE (Hall, Melin, \& Nordqvist, 2001) and can further our understanding of this phenomenon.

The scholarly approach to CE in family firms, however, has mostly neglected the variety of $\mathrm{CE}$ forms, and mainly considered the preference or reluctance of family firm towards $\mathrm{CE}$ as constant over time (Sharma et al., 2014b). This prevents us from a clear understanding of CE dynamics in family firms. In particular, despite recent calls for investigation (Hoy, 2006; McKelvie et al., 2013), our understanding of the how, when and why family businesses (FBs) undertake CE initiatives (Sciascia \& Bettinelli, 2013) is still poor and fragmented. To address these gaps, this paper introduces an integrative framework and conceptual extension of CE literature, following a twofold approach. First, we focus on corporate venturing (CV) as a specific 
type of CE. The role of FB in fostering new ventures and entrepreneurial initiative is of paramount economic importance (Astrachan et al., 2003; Zahra, 2005) but yet most unraveled by academic debate (Gomez-Mejia et al., 2011). We also address the focus of CV, namely internal CV (entrepreneurial activities that result in the establishment of organizational entities that reside within the mother company) versus external CV (semi-autonomous or autonomous organizational entities that reside outside the existing organizational domain) (Sharma \& Chrisman, 1999). While internal venturing deals with developing entrepreneurial initiatives that originate within existing structures of a parent firm, external venturing is manifested as the acquisition of operational ventures from the external environment of the corporation for the purpose of integrating them within the firm's organizational structure(s). Family firms' are expected to have distinctive preferences as to whether or not to engage in $\mathrm{CV}$ at all, but also whether it will be manifested with an internal or external focus.

Second, this study on CV in family business emphasizes the temporal dimension. Tagiuri \& Davis (1996) proposed a "three circle model" that characterizes family businesses through ownership, business and family dimensions. Family firms are affected by temporal dynamics, so that CV may be a function of the development, and not just the overlap, of the three dimensions that dynamically characterize a family firm. CV may thus result from the delicate and dynamic alignment of the contemporary evolution of the three systems. Our reliance on the concept of "developmental dimensions" (Gersick et al., 1997) aims to substantiate the challenging claim that family firms' entrepreneurial initiatives could be better understood by considering the "complicating factor of life cycles" (Hoy, 2006). Based on a configurational approach, this study discusses when family firms choose to engage in CV along their ownership- (ODD), family(FDD), and business developmental dimension (BDD) (Gersick et al., 1997), and which kind of CV type - internal or external - they prefer to undertake. Particularly, the coexistence of different 
developmental dimensions - with the ownership dimension playing a leading role (Nordqvist, 2005; Gomez-Mejia et al., 2011; Hoy, 2012) - is assumed to influence family firm's goals, motivations and preferences (De Massis et al., 2014a) which, in turn, are informative about significant decisions regarding not only $\mathrm{CV}$ investments in general, but also the focus of the $\mathrm{CV}$ activities undertaken. Drawing on the literature of FB goals (Chrisman et al., 2013), we develop propositions that highlight the changing value of long-term sustainability, socio-emotional preservation and the balance between economic and non-economic goals over time; we also scrutinize the effects these dimensions have on risk attitude and strategic orientation, and in turn the choice to undertake CV initiatives. The focus of the analysis covers the different stages of the ODD and considers its alignment (entrainment) with FDD and BDD. We enrich previous approaches on the importance of 'life-cycles' in CV by (1) extending it with the discussion of the erratic, arithmetic and geometric nature of developmental patterns of CV through ODD, BDD and FDD respectively; and (2) recognizing the reversible nature of these patterns.

Our paper contributes to the literature in several ways. We add to entrepreneurship research by showing that involvement in $\mathrm{CV}$, and the choice of CV focus depends on time (Lerner et al., 2007). In addition, considering family firms' dominance among entrepreneurial firms, we contribute by indicating family business system dynamics as a potential internal trigger of the $\mathrm{CE}$ process, a dimension that has been mostly overlooked by extant research (Kuratko, 2010; Phan et al., 2009). We also add to family business literature, by shedding light on how development and change over time can foster or inhibit longevity and sustainability of the firm through $\mathrm{CV}$ (Jaskiewicz et al., 2015). Furthermore, this study contributes to the ongoing debate on the role of time, in terms of entrainment of coexisting developmental dimensions and temporal personality (Sharma et al., 2014b), and their effect on CV. Finally, we address strategic management literature, by looking at individual and organizational antecedents of enduring entrepreneurship 
phenomena, as opposed to infrequent or non-recurring entrepreneurial strategies and organizational practices (Jaskiewicz et al., 2015).

\section{THEORETICAL BACKGROUND}

\section{Corporate Entrepreneurship and Corporate Venturing}

Corporate entrepreneurship refers to the set of entrepreneurial activities that can help a firm to grow from its early stage, to face the maturity, and rejuvenate to survive a corporate or market decline (Kuratko et al., 1990). The study of CE is a growing area of interest for many scholars (Phan et al. 2009) and CE has been shown to be one of the most effective method to achieve high organizational performance (Garvin \& Levesque, 2006; Kuratko, 2009; Kuratko, 2010). Accordingly, firms increasingly rely on $\mathrm{CE}$ to simultaneously develop and nurture their competitive advantage (Ireland et al., 2006a, b).

A number of definitions have been provided in extant literature and the concept of CE has evolved over time (Sharma and Chrisman, 1999; Corbett et al., 2013). One of the earliest definition of CE was provided by Guth \& Ginsberg in 1990 and included two main components: the creation of new ventures within existing organizations (corporate venturing) and the transformation of organizations via strategic renewal. Covin \& Miles (1999) defined CE through a broader approach, namely considering concepts such as sustained regeneration, organizational rejuvenation, and domain redefinition. In parallel, Sharma \& Chrisman (1999) identified three domains within which $\mathrm{CE}$ should be investigated: corporate venturing, innovation, and strategic renewal. According to the latter, hence, $\mathrm{CE}$ encompasses three types of phenomena which may or may not be interrelated: the birth of new businesses, innovation and the transformation of existing organizations through the renewal of the key ideas on which they are built. 
Corporate venturing activities represent one component of the broader CE phenomenon (Sharma \& Chrisman, 1999), and have recently received extensive scholarly attention (Covin \& Miles, 2007; Narayanan et al., 2009). CV is a recognized means through which firms may extend their core competencies, renew their strategies, or reframe their organizational boundaries (Covin \& Miles, 2007).

Corporate venturing can result in both internal corporate ventures (ICVs) and external corporate ventures (ECVs). ICVs are entrepreneurial initiatives that originate within a corporation and are intended from their inception as new businesses for the parent firm (Sharma \& Chrisman, 1999). Although ICVs activities are located within existing organizations, they may be created in different ways, having different relationships with the corporate parent, involving different levels of innovation and differing in strategic importance. Therefore, as pointed out by Sharma \& Chrisman (1999), ICVs may vary in at least four dimensions: structural autonomy, relatedness to existing business, extent of innovation, and nature of sponsorship. ECVs, instead, are new businesses initiated outside the corporate enterprise, but that are acquired from the external environment and then integrated into the corporate organizational structure. Some examples of ECVs are those formed as result of joint ventures, spin-offs, and venture capital initiatives. ICVs and ECVs are intimately different. The former deals with developing the existing organization and building innovative and entrepreneurial capabilities inwardly (Miles \& Covin, 2002), empowering employees (Reimsbach \& Hauschild, 2012), stimulating growth at incumbent's core business, for example exploring radical technological innovation, or leveraging and exploiting existing resources and capabilities (Block \& MacMillan, 1993). External corporate venturing, instead, aims at gathering quick returns from related and more lucrative markets (Miles \& Covin, 2002; Tidd and Taurins, 1999), acquiring new competencies and reducing risk, in terms of protection from unexpected technological change (Reimsbach \& Hauschild, 2012). 
The underlying motives for internal (McGrath \& Keil, 2007) and external (Dushnitsky \& Lenox, 2005b) corporate ventures are frequently implicit and undefined, which may stem from the absence of an accepted, explicit charter stating the corporation's strategy with regards to business renewal (Gee, 1994). Kuratko et al. (2009) identified several factors that influenced the success of an ICV, including venture goal clarity and support from the management of the parent organization. External venturing research tends to highlight its impact on knowledge creation or innovation performance (Keil, Maula, Schildt \& Zahra, 2008; Wadhwa \& Kotha, 2006), though there are some studies that look at measures of venturing on parent firm performance (Allen \& Hevert, 2007; Dushnitsky \& Lenox, 2006).

\section{Corporate Venturing in Family Firms}

Family firms have become an interesting ground for CV scholars (Nordqvist \& Melin, 2010; McKelvie et al., 2013). Transgenerational entrepreneurship - i.e., the process through which a family uses and develops entrepreneurial mindsets, family-influenced resources, and capabilities - allows family firms to consistently adopt innovative, risky and proactive strategic postures, thus actualizing an enduring entrepreneurship approach in the organization. Indeed, family firms aim at the long-term survival of the firm and the ability to offer employment to family members as their most important goals (Athanassiou, Crittenden, Kelly \& Marquez, 2002). Based on this, they can create value across generations and uniquely support the longevity of the business activity (Zellweger et al., 2012).

Research has shown that family firms are potentially different with respect to other businesses, as regards CV (Kotlar and De Massis, 2013; Sharma et al., 2014a). Family-centered economic and non-economic goals together with particularistic power structures, incentives and norms often characterize these firms (Carney, 2005; Gedajlovic \& Carney, 2010; Gedajlovic, 
Lubatkin, \& Schulze, 2004; Harris et al., 1994) as well as seriously affect their strategic and entrepreneurial processes (Kellermanns et al., 2008). Family firms' behavior is especially affected by the pursuit of family centered non-economic goals, like family harmony, social status and identity (Chrisman, Chua, Pearson, \& Barnett, 2012). These goals are acknowledged as particularly important for family firms (Zellweger et al., 2012), since they follow logics other than just profit (e.g., the preservation of "socioemotional” wealth, Gómez-Mejía, Haynes, NúñezNickel, Jacobson, \& Moyano-Fuentes, 2007). Priority among family centered non-economic goals depends on family involvement (Chrisman et al., 2012), so that also family firms' behavior in $\mathrm{CV}$ can be extremely heterogeneous. "For these reasons, the intersection of research in family business and corporate entrepreneurship presents fertile ground for future research efforts" (McKelvie et al., 2013, p. 341).

In the field of $\mathrm{CV}$, scholars have addressed several issues, which have been studied according to different levels of analysis, although knowledge about CV activities of family businesses is comparatively underdeveloped in comparison to what we known about $\mathrm{CE}$ in general (Chrisman, Chua, \& Sharma, 2005). Despite the acknowledgment that family firms' rich behavioral and organizational diversity should prompt family business research to contribute and inform mainstream management and entrepreneurship theories (Sharma et al., 2012), scant attention from empirical contributions (e.g., Kellermanns et al., 2006) and research systematization has been provided (McKelvie et al., 2013; Sciascia \& Bettinelli, 2013).

In particular, a major gap undermines the establishment of the field, thus calling for urgent investigation. It is not clear which is the generational stage when an entrepreneurial effort may be more likely and effective (Sciascia \& Bettinelli, 2013); or if issues, such as whether to maintain control of the business or how to manage relationships among family members, may contribute to understand how family firms engage in CV (McKelvie et al., 2013). To contribute with new 
knowledge to this research stream, Hoy (2006) suggests disentangling the different dynamic mechanisms of family influence on CV.

Overall, we still lack a clear understanding of how antecedents, boundaries, and consequences of $\mathrm{CV}$ vary along the dynamic development of family firms over time; in order to address this gap, we draw on the developmental model of family firms (Gersick et al., 1997) which we will briefly introduce in the next section.

\section{Family firms: a dynamic view}

Family businesses can be described as the sum of three independent but overlapping subsystems - business, ownership and family (Tagiuri \& Davis, 1996). The three circle model, by separating these three domains, is a very useful tool for clarifying the motivations, perspectives and hence behaviors of individuals differently positioned in the system, as well as for understanding conflicts, priorities and boundaries in family firms. For example, the decision to distribute or reinvest dividends may be better understood considering each participant's position in the three-circle model: a family member, who is an owner but not involved in the business, may prefer dividends to be distributed; conversely, a family member working in the family firm without owning its shares may prefer dividends to be reinvested in order to expand the business and create career opportunities. Thus family involvement plays a relevant role to determine family firms' behavior, that is in turn affected by which kind of goals are pursued, whether family or non-family centered goals, and economic or non-economic goals are prioritized (Andersson, Carlsen, \& Getz, 2002; Chrisman et al., 2012; Olson, Zuiker, Danes, Stafford, Heck, \& Duncan, 2003).

The downside of the original three circle model is its static nature: the model framed by Tagiuri and Davis (1996), indeed, does not consider that ownership, as well as family and 
business systems, change over time. The characteristics of each system develop across generations, as the family and the firm grow, and as other contingent elements, such as industry characteristics or market competition, interfere with the life of the family business. Especially family-centered goal setting reflects some arrangements between coalitions of organizational members at the intersection of the family, the ownership, and the business systems, that cannot be considered as static but are instead likely to change over time (Kotlar \& De Massis, 2013). Moreover, a complicating factor in pursuing the balanced set of goals of family firms over time relates to the different growth paces of the three systems (De Massis et al., 2014a), since for example business grows arithmetically, while the demands of the families grow geometrically (Miller, Le Breton-Miller, \& Scholnick, 2008). In order to make this framework more suitable to the reality of family and business organization, Gersick et al. (1997) theorize on an additional dimension to be considered: time.

The Three-Dimensional Developmental Model developed by Gersick and colleagues (1997) provides a useful framework to investigate the development of a FB over time. The dynamics of family firms, indeed, are analyzed through a combination of stages across ownership, family and businesses. Thinking “developmentally” about these three dimensions - ownership, family and business - means taking into account: (1) the temporal evolution of the family firm's ownership structure; (2) the development of family issues - such as the entry of a new generation, the authority transfer from parents to children, the relationships between siblings and cousins; (3) organizational change. While the biological metaphor of life cycle does not allow for nonlinearity, unpredictability and emergence (Wales, Monsen, and McKelvie, 2011), when considering organizations, and family firms in particular, it may be suitable to follow an approach to growth and evolution that consider the dynamic nature of firms' development (Levie \& Lichtenstein, 2010). Indeed, there are firms that on purpose remain small in terms of size and 
organizational complexity for long time, especially family-run companies (e.g., Carland et al., 1984); or it is possible to find family businesses where ownership is concentrated along the generations as a pruning strategy is adopted in the succession process (Lambrecht $\&$ Lievens, 2008).

According to Gersick and colleagues (1997), each stage of the three developmental dimensions is characterized by idiosyncratic challenges and managerial issues (see Table 1 for a summary based on Gersick et al. 1997).

Insert Table 1 about here

The Ownership Developmental Dimension describes the development of ownership as the factor that intrinsically characterizes the family business (see also Nordqvist, 2005). Changes in ownership can represent a dramatic change in firm identity, affect changes in firm strategy, and, in turn, influence its behaviors and business processes (Miller et al., 2011). The ODD consists of three stages and suggests that most business begins with ownership control consolidated in one individual or couple (controlling owner stage). Family businesses then move through the sibling partnership stage, to the cousin consortium stage, with a corresponding progressive increase in the complexity of the ownership structure. The developmental thinking, as opposed to rigid life cycle reasoning, is of particular value in analyzing the ODD. Even when single owners change, ownership structure can remain static for generations. Conversely, in most cases, ownership dilution is a slow, on-going process, that is subject to a continuous and long transitional process, rather than static and discrete-event evolution. Nonetheless, hybrid situations between different ownership stages are not infrequent, and sometimes they even last for several years. Therefore, even if the progressive approach through sequences partially describes much of family business ownership evolution, a loose interpretation should be given to this developmental phenomenon. 
Another dimension that has to be considered as relevant for a family business is Family Developmental Dimension. It relates to the family evolution and in particular to the evolving relationships among family members (Tagiuri \& Davis, 1996). Labeled as business families, these groups of people involved in a business, and simultaneously linked by blood ties, have to face several issues that change over time. Along the FDD it is possible to identify four steps (or stages) that stress the most important phases of the life of the family considered as a unit (Gersick et al, 1997). The first stage, the young business family, is characterized by an adult generation under forty with children, if any, under eighteen. During this phase the business family has to deal with the creation of a 'marriage enterprise' characterized by its style with respect to the role of each partner, whether they enmesh business and private life or instead try to separate the two systems as much as possible, thus caring about the balance between work and family, responding to the pressures coming from their extended families and discussing to what extent involving members from both parties. Later on (entering the business), the family has to recognize the role of the leader(s) who self-assess as incumbents, while teen and young adult offspring grow in the family business atmosphere; afterwards there is a phase (working together) when all family members work together and thus communication, collaboration and, in general, linking mechanisms become extremely relevant in order to avoid disruptive conflicts. Finally (passing the baton), succession issues emerge; these, while in-depth investigated in management literature, are mainly neglected if the focus is specifically on family sociological issues.

Finally, the Business Developmental Dimension (BDD) describes the development of the family business over time. BDD focuses on two key indicators of organizational change: growth - in terms of sales, volume, number of employees - and complexity of the organizational structure. It covers three stages: the start-up business stage, which corresponds to the founding of the company and the following years when survival is in question; the expansion/formalization 
stage during which business expands and organizational complexity increases; finally a phase of stasis - maturity - with an organizational structure supporting stability and very modest expectations about growth. Each business stage may last few years or be a long phase of gradual evolution, also depending on external conditions - competition, technology change, product life cycle.

In addition to recognizing the current stage in one specific developmental dimensions, the combination of stages across different developmental dimensions is thought to better identify individual and organizational priorities, opportunities and openness towards change and hence to understand FB dynamics (Gersick et al., 1997; Hoy, 2006). As suggested by Hoy (2006), indeed, entrepreneurial families need to manage the "complicating factor of life cycles", namely to simultaneously cope with multiple life cycles (individual, familial, ownership, corporate, industrial, etc.) in order to innovate and prosper. Despite the fascinating nature of this approach, conceptual and empirical validations are missing. Still, in discussing this multiplicity of coexisting DD effects in family firms, the concept of entrainment is coming to the forefront. Entrainment is "the adjustment of the pace or cycle of an activity to match or synchronize with that of another activity" (Ancona \& Chong, 1996, p. 258), and may therefore be helpful to consider not only the simultaneous presence of different developmental dimensions (Hoy, 2006), but also their synchronization (Sharma et al., 2014b) in explaining firm behavior.

\section{Evidences on Corporate Entrepreneurship dynamics along the Family Business Developmental Dimensions.}


The existing literature is characterized by ambiguity concerning the evolution of the FBs entrepreneurial behavior along the family business developmental dimensions as well as it overlooks the joint effect of the family business developmental dimensions. ${ }^{1}$

With particular reference to the ownership and family developmental dimensions ${ }^{2}$, some empirical and conceptual indeterminacies arise. A number of contributions suggest a growing pattern of CE along the ownership and family developmental dimensions. The arguments provided are: growth of the family resulting in growth of entrepreneurial activities (Marchisio et al., 2010; Webb et al., 2010; Gomez-Mejia et al., 2011), increasing long-term orientation (Lumpkin et al., 2010), higher availability of resources - such as organizational social capital, managerial capabilities, internal autonomy and successors' discretion (Mitchell et al., 2009; Wang \& Poutziouris, 2010; Zahra, 2010; Jones et al., 2013) - and greater heterogeneity of the decision-making group (Webb et al., 2010). In one of the case study analyzed by Marchisio and colleagues (2010), for instance, the growth of the family boosts corporate venturing activities as a way to avoid conflicts: "while having several family members working together in the core business could have engendered conflict, external venturing offered opportunities to separate conflicting individuals and to involve more family members who otherwise would not willingly work together" (p. 367). The counter arguments used by authors arguing a decreasing pattern of CE along the ownership and family developmental dimensions include: increasing family concerns and conflicts among the family members (Chirico \& Nordqvist, 2010; Lumpkin et al., 2011; Parker and Van Praag, 2012); family altruism (Block, 2012); family orientation (Pistrui et al., 2010; Moog et al., 2011); legacy (Welsh et al., 2013) and risk aversion (Cassia et al., 2012).

1 Since the literature on $\mathrm{CV}$ along the family business developmental dimensions is nearly nonexistent, in this section we refer to the broader concept of CE.

2 To the best of our knowledge, these two dimensions are never distinguished within extant literature and this could be explained by the sensitivity of and hence difficulty of access to data related to the family developmental dimension. 
For example, Parker and Van Praag (2012), argue that when there are many siblings it is less likely that an acquisition takes place, because there is great competition among offspring to be the successor.

There is instead consensus on the increasing pattern of CE engagement along the family firm's BDD. This is enabled by factors such as a progressive access of firms to a stock of idle resources (Kellermanns et al., 2008) and to an increasing amount of organizational social capital (Zahra, 2010). These resources, indeed, are leveraged to grow and renew the business thanks to values, norms and attitudes which characterize membership in the business family and which support entrepreneurial behavior (Nordqvist \& Melin, 2010). Moreover, CE initiatives are fostered by managerial capabilities, professionalization and outsiders' involvement in family firms' board of directors (Wong et al., 2010; Au et al., 2013), as growing family firms become aware that it is necessary to involve non-family members.

Interaction among the family business developmental dimensions has been mainly neglected. Only some case studies simultaneously capture them. Kodithuwakku and Rosa (2002), for example, report the case of family firms in the controlling owner (ODD) and start-up business (BDD) phases generating other venture activities related to the core business of the mother company. Salvato, Chirico and Sharma (2010) observe a family firm in the sibling partnership (ODD) and declining (BDD) stages and show how exit strategies, although viable, have been discarded by the firm because of a lock-in in family legacy; exit, as a specific type of entrepreneurial initiative, instead, is pursued to avoid decline (BDD) by a family firm in the cousin consortium stage (ODD) in the case analyzed by Yacob (2012). Taken together, the last two papers seems to suggest that family legacy and its effect on CE initiatives is higher in the second phase of the ODD then in the third one, BDD being equal. The few existing contributions highlights the importance of taking into account the entrainment and hence synchronization of the 
different DDs. None of them focuses specifically on CV initiatives. Overall, the fragmentary evidences coming from the extant literature on FBs entrepreneurial behavior along the different developmental dimensions corroborate the need to develop a more holistic theoretical framework through which to approach the phenomenon of CV in family firms.

\section{THEORETICAL FRAMEWORK}

\section{Assumptions}

This work builds on the view that family firms are characterized by three developmental dimensions, which mutually interact to determine different and even conflicting motives for $\mathrm{CV}$ engagement (and preferences for CV modes) over time. In doing so, and having in mind the goal of achieving parsimonious and consistent conceptual development, some necessary assumptions were made during the formulation of our propositions. First, the process of organizational goal formulation and pursuing is quite complex and many individuals are influential (Kotlar \& De Massis, 2013). Despite the multiplicity of actors and levels of analysis involved (Chrisman et al., 2005), for the case of family firms we follow Gomez-Mejia et al. (2011) by taking the perspective of the family firm principals as main decision makers and focusing on their own preference to determine the when, how and why of CV. Second, the behavioral characterization of family firms is both rich in terms of potential conceptual contribution (Sharma et al., 2014a) and dispersed in terms of theoretical perspective, in particular when referring to goal setting processes (Chrisman et al., 2013); examples range from agency theory (Chrisman et al., 2012) to stewardship theory (De Massis et al., 2014a) and socio-emotional wealth (Gomez-Mejia et al., 2007), just to name a few. Following this consideration, rather than choosing a unique theoretical framework, we build our propositions by leveraging on the richness of goal emergence and goal 
setting literature. Third, given the centrality of temporal dimensions and temporal dynamic evolution with respect to both family business and $\mathrm{CV}$, our propositions draw upon the concept of entrainment (synchronized oscillation of activities, cf. McGrath \& Rotchford, 1983). We will thus describe how the three systems individually and jointly contribute to determine $\mathrm{CV}$ in family firms, and will show how synchronization of ownership- and business- or family-related motives can lead to strategic interests for $\mathrm{CV}$ activities, to a preference for $\mathrm{ECV}$ over ICV, or viceversa. Fourth and last, our considerations embed issues related to the relationship of organizational actors to time (Sharma et al., 2014b) by accounting the dimension of temporal personality (Ancona et al., 2001); in particular we highlight how CV strategies of family firms are related to organic temporal style (Butler, 1995), and a future orientation that becomes deeper as long as the organization evolves over time (Bluedorn, 2002).

Our conceptual framework is depicted in Figure 1 and has three main characteristics - based on the previously mentioned assumptions. First, as "[a]t a theoretical level, there is broad agreement that family firms are those where a family owner exercises much influence over the firm's affairs" (Gomez-Mejia et al., 2011: p658), we identify the ODD as the main dimension characterizing family firms' behavioral dynamics (Hoy, 2012) and, in turn, proclivity for CV. Second, we consider the effect of BDD and FDD to shape goals and CV both directly and indirectly. Finally, we discuss how pursuing CV may affect family firms' positioning along its DDs.

Insert Figure 1 about here

\section{Patterns of ownership and CV preferences in family firms}


Controlling Ownership Stage. During this stage, the founder and the family members equally perceive the entrepreneurial dream as important, with the business and the family being highly overlapped in terms of resources, motivations and processes (Miller et al., 2011). Strong relational and emotional dynamics make the firm's destiny crucial to the family members, who are all likely to act as steward at this stage (Discua Cruz et al., 2013). The perfect alignment of family and business goals sets high priority to the promotion of economic well-being of the firm, rather than the pursuit of individual and particular interests. For this reason, a high level of CE is found during this phase (De Massis et al., 2014a). Furthermore during the first ODD stage, the founder is concerned with the preparation of the succession process and is prone to set actions in place that increase the likelihood of successful transitions (Gersick et al., 1997). CV in particular is a form of $\mathrm{CE}$ that is appropriate, valuable and strategic during leadership succession, both to avoid leadership conflicts among potential successors and to retain heirs not interested in the existing firm (Greidanus, 2011). CV also allows founding generation members to train and assess the offspring's skills while observing them running the venture(s) (Marchisio et al., 2010). Besides, in first-generation firms, the principal sources of capital are the "sweat equity" and financial capital invested by the owner, its family and friends (Gersick et al., 1997). Although family financial capital has psychological strings attached (Steier, 2003), it is the largest source of funding (Astrachan et al., 2003) and is normally pooled from family with lower repayment requirements in terms of payback time and interest rate (Rodriguez et al., 2009). This makes family financial capital a particularly patient source of funding that is pledged to fund short-term but also long-term investment, such as CV, and ICV in particular (Miles \& Covin, 2002). During the founding stage family firms are particularly coupled with a parental leadership style (Le Breton-Miller et al., 2014) to ensure family-control over the firm and its values. When it comes to non-family employees, father-figure leaders act as steward to the organization and people, treat 
employees as quasi-relatives, give them consideration and appreciate them for their loyalty that ensure long-term survival and reputation of the firm (Farh and Cheng, 2000). Relationships are more likely sustained by a social-exchange motivation rather than transactional approach (Clark $\&$ Mills, 2011). Human resource practices are developed with the goal of building especially bonding relationship and socialization, including hiring, training and mentoring (Miller \& Le Breton-Miller, 2005). Since ICV is particularly indicated to retain innovative-minded individuals (Priya and Viswanathan, 2005) by providing them with a proactive and entrepreneurial working environment (Scholtz, 2009), this form of venturing will be particularly likely to attract family firms' interest during the Controlling Ownership Stage.

Proposition 1a: During the Controlling Ownership Stage, family firms are willing to engage in $C V$ activities

Proposition 1b: During the Controlling Ownership Stage, family firms are more willing to engage in ICV than ECV activities

Sibling Partnership Stage. At the next step of the ODD, the Sibling Partnership Stage, family ownership is more fragmented and there is an increase of the number of the nuclear family members that receive incomes from the firm; this brings goal divergence among family members, who need to satisfy different needs at the same time. Trust less likely characterizes family relationship in a spontaneous manner and formalization is often required to ensure family harmony (Gersick et al., 1997). This multiplicity of goals decreases the overlap of business and family objectives with parochial interests prevailing over stewardship and cooperation(Corbetta and Salvato, 2004). A large number of non-active family members is likely to reduce firm's interest for CV: since they do not have managerial position, they do not benefit $\mathrm{CV}$ in terms of salary and other forms of compensation, and since the business is mostly seen as the (often unique) source of income, they are conservative and risk-averse (Zahra, 2005). Strategic conflicts 
regarding the firm's strategy are likely to be even more salient at this stage: CV requires explicit and honest discussion, with shared understanding, while during Sibling Partnership Stage firms are characterized by higher principal-principal agency conflicts (especially between activeand non-active family members), procedural justice concerns and political issues (Gersick et al., 1997). These put at stake trust among siblings, create communication problems within the organization, raise discussions about the orientation of the firm with diverging views among family branches. This is reflected by a decrease in CE proclivity of family firms at this stage (De Massis et al., 2014a). These problems are more severe when ECV is concerned since internal stakeholder (like non-active family members or owners that run consolidated business units) perceive "not to obtain their fair share of resources due to external venture investment made by the corporation" (Miles \& Covin, 2002: 30), or even see the new venture as a competitor to their own business unit.

Proposition 1c: During the Sibling Partnership Stage, family firms are less willing to engage in $C V$ activities than in the previous stage

Proposition 1d: During the Sibling Partnership Stage, family firms are less willing to engage in ECV than ICV activities

Cousin Consortium Stage. During this phase, different and conflicting stimuli operate within the organization, to complicate the prediction of firm interest toward CV. On the one hand, the goal-related conflicts discussed for the previous stage result in less entrepreneurial behavior that manifests through subsequent growth limitation. The firm in its existing configuration clearly does not suffice as a response of multiple claims and requests from family members; family goals are likely to re-align with those of the firm and induce a revival of the entrepreneurial activity (De Massis et al., 2014a), either with the hope of giving rise to a family dynasty or simply to sustain financial and non-financial benefit (such as harmony and reputation) attached to the firm 
(Zellweger \& Sieger, 2012). Entrepreneurial processes can be seen as instrumental to enhance firm reputation together with the preservation of family identity (Miller et al., 2011). Finally, at this stage the cultural distance from the founder is more marked and family principals are more likely to search for new and relevant business ideas (Mils \& Covin, 07). In sum, there are elements to claim that $\mathrm{CV}$ is likely to return a preferred option of family firms.

On the other hand, controlling families become less and less salient to the firm, with family members becoming gradually passive shareholders (Gedajlovic et al., 2004), leaving the stage to professional non-family managers and owners. This makes family members' preference less likely to be the sole and main driver of organizational goals. De Massis et al., (2014a) suggest that, after an initial revival of corporate entrepreneurial strategies, firms at later stages of their ODD tend to decline the level of entrepreneurship. Additionally, political issues and stress become more likely, internal family social capital becomes looser and more diluted; unplanned exit of family members creates both internal financial gaps and emotional turmoil (G 97). Finally, rather articulated governance structures and processes are typical of this stage and produce ambivalent effects on firm's proclivity towards CV: "Active boards are rare in family business of any size, but they are more common in Cousin Consortium - although they are still likely to be heavily dominated by family members. Most Cousin Consortium boards are constituent in nature, with some formula for representation of family branches. Although family constituent boards can be quite professional and effective, they tend to focus too much on the personal interest of branches, rather than confronting tough strategic issues facing the company" (Gersick et al., 1997: p52).

Proposition le: During the Cousin Consortium Stage, it is unclear whether family firms are more or less likely to be willing to engage in $C V$ (and ECV or ICV) activities than in the previous stages 


\section{The direct and indirect effect of business and family developmental dimensions}

Business Developmental Dimension. In line with existing literature, we advocate that the preferences of family firms along their BDD are much more straightforward and predictable, in particular they are positively associated with willingness to engage in $\mathrm{CV}$. When firms grow and stabilize they accumulate resources and are more likely to originate slack, resource in excess to the ongoing needs of the firm (George, 2005); these resources can be allocated to a diverse set of activities, that are in line with firms' goals. They represent a mean to pursue the dominant coalition's preferences, either economic or non-economic (Kim et al., 2008). Much literature advocates that surplus resources can be an antecedent of performance and innovation, and specifically it is suggested that slack resources are organizational antecedent of CV (Burgelman, 1983; Greidanus, 2011). Along the corporate development, firm professionalization increases and family firms are more likely to develop family-centered economics goals, such as growth and business development (Marchisio et al., 2010). Therefore, surplus resources represent an inducement to pursuing CV (Kim et al., 2008). Among the different types of resources that a firm accumulates over time, human resources are crucial to larger organizations (Voss et al. 2008); when it comes to growing or maturing family firms, the preservation of employment and the qualification of human resources represent prominent purposes both from an economic (challenge top management team inertia, develop and nurture next generation leaders) and a non-economic (provide employment to family members or individual in the community, retain talents, enhance firm reputation) point of view (Le Breton-Miller \& Miller, 2014). Given the value of CV to human resource management and preservation (Hayton, 2005; Covin \& Miles, 2007; De Bettignies \& Chemla, 2008) it is more likely that along the BBD, family firm will see CV as a valuable organizational option. At later stages of BDD family firms are seriously concerned with both external and internal threatens to firm survival; inertia, path dependence, lack of innovation 
and decline in product and technology are likely at this point(Gersick et al., 1997). It is at these stages that $\mathrm{CV}$ represents a particularly valuable option, given its role in organization rejuvenation and renewal (Markham, Gentry, Hume, Ramachandran, \& Kingon, 2005; Pittaway, 2001). Cognizant of this advantage, firms' principals will see CV as an option to have access to new technologies and markets (Markham et al., 2005), drive the change and exploit environmental opportunities (Scholtz, 2009; Priya \& Viswanathan, 2005), experiment organizational innovations (Markham et al., 2005) and grow (Kuratko et al., 2011).

External venturing represents a way to achieve rapid change and financial returns (Miles \& Covin, 2002), fast learning from radical technologies and emerging fields (Schildt et al., 2005; Weber and Weber, 2007), enhancing firm's innovation capabilities (King et al, 2003; Dushnitsky and Lenox, 2005) when organizational inertia is high. In these cases, family firms may ceteris paribus more likely need to counter endogenous and exogenous decline with quick actions that do not upset and overturn the organization, preserving existing firm processes, capabilities and culture. Organization systems and policies, professional hiring and authority delegation may, in this sense, be aligned with firm willingness to renew and support the undertaking of ECV activities. Furthermore, talent retention, training and incentives are central to mature firms, as qualified individuals may be attracted by the opportunities and returns they observe elsewhere in new ventures. Firms principals, especially in family firms (Le Breton-Miller \& Miller, 2014), may be aware of the importance to retain "stars", induce them to exert more efforts and allow them more autonomy and control rights (De Bettignies \& Chemla, 2008). When more control rights and managerial independence is granted to corporate ventures, these more markedly resemble ECV forms. Finally, mature family firms may see ECV as a mean to sustain reputation, to signal innovation commitment (especially when the mother company is in mature, low tech industries) (Miles \& Covin, 2002) and to communicate high willingness to engage in ECV as a 
route to partnering with external organizations (Gersick et al., 1997). External partners are valuable as they represent vehicle to keyresources, both financial and non-financial; given the need for such resources, family owners may abandon their usual reluctance for control relinquishment (Gomez-Mejia et al., 2011) and show unexpectedly high level of openness and reliance on external partner to run ECV.

Proposition 2a: Proceeding along the BDD, family firms' willingness to engage in CV initiatives increases

Proposition 2b: Proceeding along the BDD, family firms' willingness to engage in ECV becomes higher than ICV

Family Developmental Dimension. When families grow, they do so more quickly than their business. While businesses grow arithmetically, families and their demands to the firm are said to grow geometrically (Miller et al., 2008). Family firms with growing families may see CV as a valuable option to avoid leadership conflicts among offspring (Greidanus, 2011) and retain heirs that are not committed onto the incumbent firm (Marchisio et al., 2010). Family leaders may see $\mathrm{CV}$ as a response to offspring's request to create their own business and to show their own skills (Marchisio et al., 2010) thus reducing the family pressure toward the parent business coming from non-active or non-committed family stakeholders. When families are still close to the initial nuclear family, venturing, if desirable at all, may be limited to ICV. The intertwinement of family and business capital allows the business for longer temporal orientation and return perspectives, which make the firm more tolerant to the high risk and organizational commitment required by ICV (Miles \& Covin, 2002). At early stage of FDD the firm is likely to be confident on internal knowledge creation, and more interested to high degrees of relatedness when doing CV (Gersick et al., 1997). Finally, non-economic goals such as control over the business and preparation of succession processes are high on the agenda of firm principals. Conversely, when family progress their FDD, ECV is likely to become the more preferred option since family leaders may place 
more urgency on the achievement of organizational outcomes that serve family centered economic and non-economic motives such as: obtaining more rapid financial returns (Miles \& Covin, 2002), rapid access to technologies and markets and organizational change (Markham et al., 2005). ECV forms such as acquisitions may be preferred to internal development when the resources the parent firms is looking for are distant from current firm knowledge (Capron \& Mitchell, 2009; Kogut \& Zander, 1992) and when innovation speed is important. We advocate this temporal pressure is placed higher when FDD is at later stage and family patriarchs approach the end of their lifespan.

Proposition 3a: Proceeding along the FDD, family firms' willingness to engage in $C V$ initiatives increases

Proposition 3b: Proceeding along the FDD, family firms are initially more willing to perform ICV initiatives than external ones. Approaching the end of the FDD, this trend is reversed (family firms are more willing to perform ECV initiatives than internal ones)

One of the advantages of Gersick et al. (1997)'s conceptualization of family firm developmental system is that it allows isolating the different components of the family business system and examining them separately. While anecdotal evidence suggests that progression along the three DDs may be somewhat correlated, it is not impossible to generalize and think of larger firms being still run by the founder, or small firms being owned by a $6^{\text {th }}$ generation family in a cousin consortium stage. Especially due to the erratic nature of ODD evolution but also to possible discontinuities (e.g., divorces and death) in the family development and non-linear progress of business growth, the three systems may find themselves at very different stages and their interaction is deemed to offer an extension or even clarification of the predictions offered above. While not exhaustive, the following represent examples that are insightful and central to the family business and CE literature. 
The Moderating Role of Business Developmental Dimension. We argued above that one of the reasons for the ambiguity regarding family firms' preferences for $\mathrm{CV}$ at the cousin consortium stage (ODD) is due to the different roles of board structure and functioning. Filatotchev et al. (2006) suggest that functions of corporate governance can be referred to as monitoring, resource provision and strategic support. The authors also suggest that the balance of these dimensions and their effect on firm rejuvenation are different along the evolution of the organizational structure (a dimension that can be ascribed to BDD in our conceptualization). At initial BDD stages agency problems are not as established as in maturing firms (Certo et al., 2001), and the main contribution of (independent) board is to support firm with resources, strategic flexibility and long term focus on growth. Firms at this stage may be, all else being equal, more prone to act entrepreneurially, e.g., by undertaking CV initiatives. As the firm matures, the corporate governance system gains importance and shifts its balance toward monitoring and control; different types of principal-principal conflicts are more likely to emerge (Fama and Jensen, 1983), particularly in family firms (Miller et al., 2011), and in the context of strategic decisions such as innovation (De Massis et al., 2013) or the allocation of surplus resources (Greidanus, 2011). Firms principals and board members might become more concerned with balancing the requests of different family branches; moreover, conflicts regarding resource allocation become more severe. Paradoxically, at this stage firms may more likely humor and contribute to self-serving managerial behavior and entrenchment (Gibbs, 1993), thus stressing family-centered non-economic goals that hamper firm's willingness to engage in CV.

Proposition 4a: During the Cousin Consortium Stage, family firms are more willing to engage in $C V$ activities when the business is at earlier stages of the BDD

The Moderating Role of Family Developmental Dimension. At sibling partnership stage (ODD), as we have advocated, family firms are less prone to engage in CV and ECV in 
particular. At this stage firms experience a great tension between dividends distribution and reinvestment policies. While the former choice allows for family-centered motives such as personal leisure or even individual investment in new activities (like a new venture separated by the incumbent family firm; Marchisio et al., 2010), the latter responds to firm-centered economic motives such as innovation and growth (Gersick et al., 1997). We suggest that the solution of this dilemma might be contingent on family-related dimensions such as the progress along the FDD. Larger families in business (Nordqvist and Melin, 2010) may be characterized by a higher number of passive members who see the business as a source of income. They will put family pressure on the business toward distribution and harvesting policies (Gersick et al., 1997; De Massis et al., 2014a); this will make CV lower in firm priority. Larger families are also likely to increase goal conflict, trust reduction and lack of support to $\mathrm{CV}$ policies, especially when in-laws are brought into play (Gersick et al., 1997). Non-active family members will also be less concerned with the reputational advantages of CV (Miles \& Covin, 2002). Finally, they are more likely to desire sudden exit and advance cash-out requests that will hamper firm's liquidity.

Proposition 4b: During the Sibling Partnership Stage, family firms are even less willing to engage in $C V$ activities when the family is at later stages of the FDD

\section{The effect of $\mathrm{CV}$ on the family business developmental system}

CV “enables firms to opportunistically reinvent themselves" (Miles and Snow, 2007: p.188) and develop enduring entrepreneurship across generations. Since most common outcomes for CV are renewal, rejuvenation and survival, the (successful) implementation of $\mathrm{CV}$ is expected to have effects on the family business and the dynamic evolution of family firm developmental system. For example, one of the critical decisions an owner normally faces is to choose an ownership structure for the next generation; two possible alternatives are (1) to invest in one individual or (2) to divide ownership among a group of heirs (Gersick et al., 1997). This decision is very likely 
to be influenced by hypothetical CV initiatives performed in the recent past, for at least four reasons (Marchisio et al., 2010). First, the owner might have observed the next generation during the venturing process, and have learnt about individuals' skills and preferences. Second, the quality of the relationship between founding and next generations may have increased or decreased, depending on the success of the CV initiative(s) (e.g., family cohesion). Third, the outcome of the venturing process might be the growth of the new venture, which has gained prominence in the market and has become an independent firm, with its own ownership structure; this creates two new, different and possibly separated development courses of ownership, one in the mother company and one in the venture. Finally, CV may engender conflicts on the management of the new venture, "turf wars" over resource allocation and resentments (Miles \& Covin, 2002) that accelerate the exit of family shareholders and the sudden change of the ownership configuration. In a similar fashion, CV initiatives are likely to impact family firm's position in the BDD; successful venturing generates growth and profits or help firms coping with market maturity and technology decline. In addition, one of the benefits of CV is represented by knowledge and managerial spillover from the new venture (especially when it is external) to the mother companies (De Bettignies \& Chemla, 2008). New capabilities life cycles may result from venturing and partnering with external players, such as academic institutions or (corporate) venture capitalists (Dushnitsky and Lenox, 2005). Organizational growth, renewal or even restart are not unlikely outcomes of $\mathrm{CV}$, especially at later stage of the BDD.

Proposition 5: A family firm's position in $O D D$ and BDD is affected by preceding $C V$ activities

\section{DISCUSSION}


The present work contributes to $\mathrm{CE}$ and FB literature in several ways. First, by describing family firm-specific dynamics underlying the willingness to engage in $\mathrm{CV}$, it shows the pertinence, relevance and appropriateness of enquiring CE dynamics in the domain of family firms (Hoy 2006; McKelvie et al., 2013); it also advocates the role of FB in advancing mainstream strategic management and entrepreneurship domains. At the same time, $\mathrm{CE}$ and $\mathrm{CV}$ in particular, offer unique opportunities to family firms for long-term, transgenerational prosperity through enduring entrepreneurship (Jaskiewicz et al 2015). Second, the central focus of our conceptualization is represented by temporal dynamics that include (a) change and instability as internal trigger to entrepreneurship, (b) long-term consequences of entrepreneurial actions, (c) emergence of heterogeneous and diverse goals, and (d) the importance of understanding alignment and entrainment among different, time-variant, components of the family business system. Taken together, these elements indicate the value of, and contribute to, research on time and temporal dynamics in management (Ancona et al., 2001), CE (Lerner et al., 2007) and FB (Sharma et al., 2014b). Third, by adopting the perspective of goal emerge and evolution in family firms, this paper generates new knowledge at the crossroads between FB and organizational behavior literature. Sharma et al. (2014a). Family firms represent an intriguing context to increase our understanding of behavioral topics related to goal, commitment and conflict; this paper indeed leverages the unique traits of these organizations due to the compresence of the family, the business and the ownership systems to offer a contribution to both literature streams.

Having said that, our paper suffers some limitations that represent opportunities for future research. We limit our discussion to CE adoption while other aspects of the $\mathrm{CE}$ process such as top management teams, incentives, individual, roles and leadership play a role in determining firm's entrepreneurial strategy. Besides, we limit our discussion to CV as a very specific form of 
$\mathrm{CE}$, and to family firm principals' strategic perspective. Embracing the recently suggested process framework of CE (Kuratko, 2010) would allow future research to overcome these limitations and extend the validity of our approach in a rigorous and parsimonious way. Furthermore, we encourage FB scholars to delve deeper into the CE process, as micro-, mesoand macro-level perspectives may further shed light on the uniqueness and distinctiveness of how family firms perform CE.

Despite the value of examining how motivations to engage in CV change over time, it has to be acknowledged that family firms' idiosyncratic behavior is ultimately the result of willingness and ability. Although our discourse is not meant to suggest that family firm will necessarily undertake CE following the goals perspective over time, it is important to stress that, when it comes to family firms' actual behavior, ignoring the simultaneous role of willingness and ability will lead to both conceptual and empirical indeterminacies (De Massis et al., 2014b). We encourage future research intended to explain $\mathrm{CE}$ behavior and performance to consider both elements. Furthermore, CE literature is maturing from a simple description of phenomena, towards an instrumental "advocacy" (Corbett et al., 2013), that means to theoretically and empirically contribute also to the understanding of outcomes of $\mathrm{CE}$, for instance in terms of both parent and venture performance. When doing this, the willingness-ability perspective seems particularly appropriate, for example to disentangle the role of governance modes, knowledge and resources in family firms.

The distinctive context in which corporate ventures operate lends itself to potentially interesting investigations and challenges. Corporate ventures are essentially businesses within a business (Garrett, 2010), managed as experiments where the parent's dominant logic (Zahra, Nielsen, \& Bogner, 1999), strategic objectives, and planning processes are often (mis)applied (McGrath \& MacMillan, 1995). When investigating this unique context, a variety of levels are 
available for analysis: individuals within the venture, the venture itself, the venturing unit of the parent corporation, and parent corporation outcomes. Research questions are plentiful in each of these levels (i.e., motivating and rewarding employees in ventures, managing ventures appropriately, the effects of venturing on corporate parents), but there are also challenges for researchers to access the data. As reviewed by Garrett (2010), data on corporate venturing can be difficult to access. Secondary data is often unavailable or inappropriate, and primary data collection efforts can be problematic because of the difficulties in identifying companies involved in venturing, securing parent company participation to discuss new business initiatives that would remain otherwise undisclosed to the public, and biases inherent in collected primary data on new businesses. However, the examination of corporate venturing in family firms may be a useful context to mitigate some of these challenges. Family firms have been found to be, in general, more willing to share their histories and new ideas. Also, dealing with family members within a family firm may allow for a greater shared memory of previous ventures explored, thus minimizing data collection concerns such as retrospective recall bias, recency bias, and performance bias.

Finally, the conceptualization of time goes beyond objective time (Sharma et al., 2014b); time is a socially constructed dimension that can be subjective (Ancona et al., 2001) and retrospectively influenced (Le Breton-Miller \& Miller, 2014). We encourage FB scholars to embrace, particularly through qualitative and longitudinal analysis, the way individuals establish their relationship with time, based on legacies, early family history and identities (Le BretonMiller \& Miller, 2014). This might shed light on how and why individuals see family firms as the proper context to feed their entrepreneurial motivations and endeavor. 


\section{CONCLUSION}

Although research has labeled "family as the oxygen that feeds the fire of entrepreneurship" (Rogoff and Heck, 2003: 559) and CE scholars have found the study of FB of great interest (Hoy, 2006; McKelvie et al., 2013), we know little about how family firms pursue CE along their evolution. In an attempt to explicate the articulated relationship between the evolutionary components of the family business system and firm's goal, this paper offer a nuanced view on (1) when and how family firms are willing to engage in $\mathrm{CE}$, (2) how $\mathrm{CE}$ can affect the inevitable but erratic pattern of family firm evolution over time. 


\section{REFERENCES}

Allen, S. A., \& Hevert, K. T. (2007). Venture capital investing by information technology companies: Did it pay?. Journal of Business Venturing, 22(2), 262-282.

Ancona, D., \& Chong, C. L. (1996). Entrainment: Pace, cycle, and rhythm in organizational behavior. In Staw, Barry M., Cummings, L. L. (Eds) (1996). Research in organizational behavior: An annual series of analytical essays and critical reviews, Vol. 18. US: Elsevier Science/JAI Press.

Ancona, D. G., Goodman, P. S., Lawrence, B. S., \& Tushman, M. L. (2001). Time: A new research lens. Academy of Management Review, 26(4), 645-663.

Andersson, T., Carlsen, J., \& Getz, D. (2002). Family business goals in the tourism and hospitality sector: Case studies and cross-case analysis from Australia, Canada, and Sweden. Family Business Review, 15(2), 89-106.

Astrachan, J. H., \& Shanker, M. C. (2003). Family businesses' contribution to the US economy: A closer look. Family business review, 16(3), 211-219.

Athanassiou, N., Crittenden, W. F., Kelly, L. M., \& Marquez, P. (2002). Founder centrality effects on the Mexican family firm's top management group: Firm culture, strategic vision and goals, and firm performance. Journal of World Business, 37(2), 139-150.

Au, K., Chiang, F. F., Birtch, T. A., \& Ding, Z. (2013). Incubating the next generation to venture: The case of a family business in Hong Kong. Asia Pacific Journal of Management, 30(3), 749-767.

Block, J. H. (2012). R\&D investments in family and founder firms: An agency perspective. Journal of Business Venturing, 27(2), 248-265.

Bluedorn, A.C., 2002. The Human Organization of Time. Stanford University Press, Stanford, CA.

Butler, R. (1995). Time in organizations: Its Experience,. Explanations and

Effects. Organization studies, 16(6), 925-950.

Carland, J. W., Hoy, F., Boulton, W. R., \& Carland, J. A. C. (1984). Differentiating entrepreneurs from small business owners: A conceptualization. Academy of Management Review, 9(2), 354-359.

Carney, M. (2005). Corporate governance and competitive advantage in family-controlled firms. Entrepreneurship Theory and Practice, 29 (3), 249-266.

Cassia, L., De Massis, A., \& Pizzurno, E. (2012). Strategic innovation and new product development in family firms: An empirically grounded theoretical framework. International Journal of Entrepreneurial Behaviour \& Research,18(2), 198-232.

Certo, S. T., Daily, C. M., \& Dalton, D. R. (2001). Signaling firm value through board structure: An investigation of initial public offerings. Entrepreneurship Theory and Practice, 26(2), 33-50.

Chirico, F., \& Nordqvist, M. (2010). Dynamic capabilities and trans-generational value creation in family firms: The role of organizational culture. International Small Business Journal, 28(5), 487-504.

Chrisman, J. J., Chua, J. H., Pearson, A. W., \& Barnett, T. (2012). Family Involvement, Family Influence, and Family-centered Non-economic Goals in Small Firms. Entrepreneurship Theory and Practice, 36(2), 267-293.

Chrisman, J. J., Sharma, P., Steier, L. P., \& Chua, J. H. (2013). The Influence of Family Goals, Governance, and Resources on Firm Outcomes. Entrepreneurship Theory and Practice, 37(6), 1249-1261. 
Chrisman, J. J., Chua, J. H., \& Sharma, P. (2005). Trends and directions in the development of a strategic management theory of the family firm.Entrepreneurship theory and practice, 29(5), 555-576.

Chrisman, J. J., Chua, J. H., Pearson, A. W., \& Barnett, T. (2012). Family Involvement, Family Influence, and Family-centered Non-economic Goals in Small Firms. Entrepreneurship theory and practice, 36(2), 267-293.

Chua, J. H., Chrisman, J. J., \& Sharma, P. (1999). Defining the family business by behavior. Entrepreneurship theory and practice, 23, 19-40.

Clark, M. S., \& Mills, J. R. (2011). A theory of communal (and exchange)

relationships. Handbook of theories of social psychology. Los Angeles, CA: Sage Publications, 232-250.

Corbett, A., Covin, J. G., O'Connor, G. C., \& Tucci, C. L. (2013). Corporate Entrepreneurship: State-of-the-Art Research and a Future Research Agenda.Journal of Product Innovation Management, 30(5), 812-820.

Corbetta, G., \& Salvato, C. (2004). Self-Serving or Self-Actualizing? Models of Man and Agency Costs in Different Types of Family Firms: A Commentary on "Comparing the Agency Costs of Family and Non-family Firms: Conceptual Issues and Exploratory Evidence". Entrepreneurship Theory and Practice,28(4), 355-362.

Covin, J.G. \& Miles, M.P. (1999). Corporate entrepreneurship and the pursuit of competitive advantage. Entrepreneurship Theory and Practice, 23(3), 47-63.

Covin, J. G., \& Miles, M. P. (2007). Strategic use of corporate venturing.Entrepreneurship Theory and Practice, 31(2), 183-207.

De Bettignies, J.-E., \& Chemla, G. 2008. Corporate venturing, allocation of talent, and competition for star managers. Management Science, 54(3): 505-521.

De Massis, A., Frattini, F., Pizzurno, E., \& Cassia, L. (2013). Product innovation in family versus nonfamily firms: an exploratory analysis. Journal of Small Business Management. De Massis, A., Chirico, F., Kotlar, J., \& Naldi, L. (2014). The temporal evolution of proactiveness in family firms: The horizontal S-curve hypothesis. Family Business Review, 27(1), 35-50.

Dushnitsky, G., \& Lenox, M. J. (2005). When do firms undertake R\&D by investing in new ventures?. Strategic Management Journal, 26(10), 947-965.

Dushnitsky, G., \& Lenox, M. J. (2006). When does corporate venture capital investment create firm value?. Journal of Business Venturing, 21(6), 753-772.

Dushnitsky, G., \& Lenox, M. J. (2005). When do incumbents learn from entrepreneurial ventures?: Corporate venture capital and investing firm innovation rates. Research Policy, 34(5), 615-639.

Fama, E. F., \& Jensen, M. C. (1983). Agency problems and residual claims. Journal of Law and Economics, 327-349.

Farh, J. L., \& Cheng, B. S. (2000). A cultural analysis of paternalistic leadership in Chinese organizations. Management and organizations in the Chinese context, 84-127.

Filatotchev, I., Toms, S., \& Wright, M. (2006). The firm's strategic dynamics and corporate governance life-cycle. International Journal of Managerial Finance,2(4), 256-279.

Garvin, D. A., \& Levesque, L. C. (2006). Meeting the challenge of corporate entrepreneurship. Harvard Business Review, 84(10), 102-12.

Gedajlovic, E., \& Carney, M. (2010). Markets, hierarchies, and families: Toward a transaction cost theory of the family firm. Entrepreneurship Theory and Practice, 34(6), 1145-1172. 
Gedajlovic, E., Lubatkin, M. H., \& Schulze, W. S. (2004). Crossing the threshold from founder management to professional management: A governance perspective. Journal of Management Studies, 41(5), 899-912.

George, G. (2005). Slack resources and the performance of privately held firms. Academy of Management Journal, 48(4), 661-676.

Gersick, K.E., Davis, J.A., Hampton, M.M., \& Lansberg, I. (1997). Generation to generation: Life cycles of the family business. Boston: Harvard Business School Press.

Gomez-Mejia, L. R., Cruz, C., Berrone, P., \& De Castro, J. (2011). The bind that ties: Socioemotional wealth preservation in family firms. Academy of Management Annals, 5(1), 653-707.

Gómez-Mejía, L. R., Haynes, K. T., Núñez-Nickel, M., Jacobson, K. J., \& Moyano-Fuentes, J. (2007). Socioemotional wealth and business risks in family-controlled firms: Evidence from Spanish olive oil mills. Administrative science quarterly, 52(1), 106-137.

Greidanus, N. S. (2011). Corporate venturing in family firms: a strategic management approach. International Journal of Entrepreneurial Venturing,3(2), 125-148.

Guth, W. D., \& Ginsberg, A. (1990). Guest editor's introduction. Corporate entrepreneurship. Strategic Management Journal, 11, 5-15.

Hall, A., Melin, L., \& Nordqvist, M. (2001). Entrepreneurship as radical change in the family business: Exploring the role of cultural patterns. Family Business Review, 14(3), 193-208. Harris, D., Martinez, J. I., \& Ward, J. L. (1994). Is Strategy Different for the Family-Owned Business?. Family Business Review, 7(2), 159-174.

Hayton, J., Chandler, G. N., \& DeTienne, D. R. (2011). Entrepreneurial opportunity identification and new firm development processes: a comparison of family and non-family new ventures. International Journal of Entrepreneurship and Innovation Management, 13(1), 12-31.

Hoy, F. (2006). The complicating factor of life cycles in corporate venturing. Entrepreneurship Theory and Practice, 30(6), 831-836.

Hoy, F. (2012). Book review: keeping the family business healthy: how to plan for continuing growth, profitability, and family leadership. Family Business Review, 25(1), 117-120. Ireland, R. D., Kuratko, D. F., \& Morris, M. H. (2006a). A health audit for corporate entrepreneurship: innovation at all levels: part I. Journal of Business Strategy, 27(1), 10-17. Ireland, R. D., Kuratko, D. F., \& Morris, M. H. (2006b). A health audit for corporate entrepreneurship: innovation at all levels: part II. Journal of Business Strategy, 27(2), 21-30. Jaskiewicz, P., Combs, J. G., \& Rau, S. B. (2015). Entrepreneurial legacy: Toward a theory of how some family firms nurture transgenerational entrepreneurship. Journal of Business Venturing, 30(1), 29-49.

Jones, O., Ghobadian, A., O'Regan, N., \& Antcliff, V. (2013). Dynamic capabilities in a sixthgeneration family firm: Entrepreneurship and the Bibby Line. Business History, 55(6), 910-941. Keil, T., Maula, M., Schildt, H., \& Zahra, S. A. (2008). The effect of governance modes and relatedness of external business development activities on innovative performance. Strategic Management Journal, 29(8), 895-907.

Kim, H., Kim, H., \& Lee, P. M. (2008). Ownership structure and the relationship between financial slack and R\&D investments: Evidence from Korean firms. Organization Science, 19(3), 404-418.

Kodithuwakku, S. S., \& Rosa, P. (2002). The entrepreneurial process and economic success in a constrained environment. Journal of Business Venturing, 17(5), 431-465. 
Kuratko, D., Hornsby, J., \& Montagno, R. (1990). Developing an intrapreneurial assessment instrument for an effective corporate entrepreneurial environment. Strategic Management Journal. 11: 49-58.

Kuratko, D. F., Morris, M. H., \& Covin, J. G. (2011). Corporate innovation and entrepreneurship.

Kurakto, D. (2009). The Entrepreneurial imperative of the 21st century. Business Horizons , 52 (5), 421-428.

Kuratko, D. F. (2010). Corporate entrepreneurship: An introduction and research review. In Handbook of Entrepreneurship Research (pp. 129-163). Springer New York.

Kuratko, D. F., Covin, J. G., \& Garrett, R. P. (2009). Corporate venturing: insights from actual performance . Business Horizons , 52 (5), 459-467.

Lambrecht, J., \& Lievens, J. (2008). Pruning the family tree: An unexplored path to family business continuity and family harmony. Family Business Review, 21(4), 295-313.

Le Breton-Miller, I., \& Miller, D. (2014). Temporal considerations in the study of family firms: Reflections on "the study of organizational behaviour in family business". European Journal of Work and Organizational Psychology, (ahead-of-print), 1-5.

Levie, J., \& Lichtenstein, B. B. (2010). A terminal assessment of stages theory: Introducing a dynamic states approach to entrepreneurship. Entrepreneurship Theory and Practice, 34(2), $317-350$.

Lumpkin, G. T., Brigham, K. H., \& Moss, T. W. (2010). Long-term orientation: Implications for the entrepreneurial orientation and performance of family businesses. Entrepreneurship and Regional Development, 22(3-4), 241-264.

Lumpkin, G. T., Steier, L., \& Wright, M. (2011). Strategic entrepreneurship in family business. Strategic Entrepreneurship Journal, 5(4), 285-306.

Marchisio, G., Mazzola, P., Sciascia, S., Miles, M., \& Astrachan, J. (2010). Corporate venturing in family business: The effects on the family and its members. Entrepreneurship and Regional Development, 22(3-4), 349-377.

Markham, S. K., Gentry, S. T., Hume, D., Ramachandran, R., \& Kingon, A. I. (2005).

Strategies and tactics for external corporate venturing. Research-Technology

Management, 48(2), 49-59.

McGrath, R. G., \& Keil, T. (2007). The value captor's process: getting the most out of your new business ventures. Harvard business review, 85(5), 128-36.

McGrath, J. E., \& Rotchford, N. L. (1983). Time and behavior in organizations. Research in Organizational Behavior, 5, 57-101.

McKelvie, A., McKenny, A., Lumpkin, G. T., \& Short, J. C. (2013). Corporate entrepreneurship in family businesses: Past contributions and future opportunities. In Melin, L., Nordqvist, M., \& Sharma, P. (Eds), The SAGE Handbook of Family Business. Sage Miles, M. P., \& Covin, J. G. (2002). Exploring the practice of corporate venturing: Some common forms and their organizational implications.Entrepreneurship Theory and Practice, 26(3), 21-40.

Miller, D., Breton-Miller, L., \& Lester, R. H. (2011). Family and lone founder ownership and strategic behaviour: Social context, identity, and institutional logics. Journal of Management Studies, 48(1), 1-25.

Miller, D., Breton-Miller, L., \& Scholnick, B. (2008). Stewardship vs. stagnation: An empirical comparison of small family and Non-Family businesses. Journal of Management Studies, 45(1), 51-78. 
Mitchell, J. R., Hart, T. A., Valcea, S., \& Townsend, D. M. (2009). Becoming the boss: Discretion and postsuccession success in family firms. Entrepreneurship Theory and Practice, 33(6), 1201-1218.

Moog, P., Mirabella, D., \& Schlepphorst, S. (2011). Owner orientations and strategies and their impact on family business. International Journal of Entrepreneurship and Innovation Management, 13(1), 95-112.

Narayanan, V. K., Yang, Y., \& Zahra, S. A. (2009). Corporate venturing and value creation: a review and proposed framework. Research Policy, 38(1), 58-76.

Nordqvist, M., \& Melin, L. (2010). Entrepreneurial families and family firms.

Entrepreneurship and Regional Development, 22(3-4), 211-239.

Nordqvist, M. (2005). Familiness in top management teams: Commentary on Ensley and Pearson's "an exploratory comparison of the behavioral dynamics of top management teams in family and nonfamily new ventures: Cohesion, conflict, potency, and consensus". Entrepreneurship Theory and Practice, 29(3), 285-292.

Olson, P. D., Zuiker, V. S., Danes, S. M., Stafford, K., Heck, R. K., \& Duncan, K. A. (2003). The impact of the family and the business on family business sustainability. Journal of Business Venturing, 18(5), 639-666.

Parker, S. C., \& van Praag, C. M. (2012). The entrepreneur's mode of entry: Business takeover or new venture start?. Journal of Business Venturing, 27(1), 31-46.

Phan, P. H., Wright, M., Ucbasaran, D., \& Tan, W. L. (2009). Corporate entrepreneurship: Current research and future directions. Journal of Business Venturing, 24(3), 197-205.

Pistrui, D., Murphy, P. J., \& Deprez-Sims, A. S. (2010). The transgenerational family effect on new venture growth strategy. International Journal of Entrepreneurship and Innovation Management, 12(1), 3-16.

Pittaway, L. (2001). Corporate enterprise: a new reality for hospitality organisations?. International Journal of Hospitality Management, 20(4), 379-393.

Reimsbach, D., \& Hauschild, B. (2012). Corporate venturing: an extended typology. Journal of Management Control, 23(1), 71-80.

Rodriguez, P., Tuggle, C. S., \& Hackett, S. M. (2009). An exploratory study of how potential "family and household capital" impacts new venture start-up rates. Family Business Review, 22(3), 259-272.

Salvato, C., Chirico, F., \& Sharma, P. (2010), A farewell to the business: Championing exit and continuity in entrepreneurial family firms. Entrepreneurship \& Regional Development: An International Journal, 22(3-4), 321-348.

Schildt, H. A., Maula, M. V., \& Keil, T. (2005). Explorative and exploitative learning from external corporate ventures. Entrepreneurship Theory and Practice, 29(4), 493-515.

Sciascia, S., \& Bettinelli, C. (2013). 2. Corporate Entrepreneurship in Family Businesses: past, present and future research.M@n@gement, 16(4), 422-432.

Sharma, P., Salvato, C., \& Reay, T. (2014). Temporal dimensions of family enterprise research. Family Business Review, 27(1), 10-19

Sharma, P., \& Chrisman, J. (1999). Toward a reconciliation of the definitional issues in the field of corporate entrepreneurship. Entrepreneurship Theory and Practice, 23, 11-27.

Sharma, P., De Massis, A., \& Gagne, M. (2014). Family business: A fertile ground for research on time, teams and positive organizational study. European Journal of Work and Organizational Psychology, (ahead-of-print), 1-6.

Steier, L. (2003). Variants of agency contracts in family-financed ventures as a continuum of familial altruistic and market rationalities. Journal of Business Venturing, 18(5), 597-618. 
Tagiuri, R., \& Davis, J. (1996). Bivalent attributes of the family firm. Family business review, 9(2), 199-208.

Tidd, J., \& Taurins, S. (1999). Learn or leverage? Strategic diversification and organizational learning through corporate ventures. Creativity and Innovation Management, 8(2), 122-129. Voss, G. B., Sirdeshmukh, D., \& Voss, Z. G. (2008). The Effects of Slack Resources and Environmentalthreat on Product Exploration and Exploitation. Academy of Management Journal, 51(1), 147-164.

Wadhwa, A., \& Kotha, S. (2006). Knowledge creation through external venturing: Evidence from the telecommunications equipment manufacturing industry. Academy of Management Journal, 49(4), 819-835.

Wales, W., Monsen, E., \& McKelvie, A. (2011). The organizational pervasiveness of entrepreneurial orientation. Entrepreneurship Theory and Practice, 35(5), 895-923. Wang, Y., \& Poutziouris, P. (2010). Entrepreneurial risk taking: empirical evidence from UK family firms. International Journal of Entrepreneurial Behaviour \& Research, 16(5), 370-388. Webb, J. W., Ketchen Jr, D. J., \& Ireland, R. D. (2010). Strategic entrepreneurship within family-controlled firms: Opportunities and challenges. Journal of Family Business Strategy, 1(2), 67-77.

Welsh, D. H., Memili, E., Rosplock, K., Roure, J., \& Segurado, J. L. (2013). Perceptions of entrepreneurship across generations in family offices: A stewardship theory perspective. Journal of Family Business Strategy, 4(3), 213-226.

Wong, Y. J., Chang, S. C., \& Chen, L. Y. (2010). Does a Family-controlled Firm Perform Better in Corporate Venturing?. Corporate Governance: An International Review, 18(3), 175192.

Yacob, S. (2012). Trans-generational renewal as managerial succession: The Behn Meyer story (1840-2000). Business History, 54(7), 1166-1185.

Zahra, S. A. (2005). Entrepreneurial risk taking in family firms. Family Business Review, 18(1), 23-40.

Zahra, S. A. (2010). Harvesting family firms' organizational social capital: A relational perspective. Journal of Management Studies, 47(2), 345-366.

Zellweger, T., \& Sieger, P. (2012). Entrepreneurial orientation in long-lived family firms. Small Business Economics, 38(1), 67-84.

Zellweger, T., Nason, R., \& Nordqvist, M. (2012). From longevity of firms to transgenerational entrepreneurship of families: Introducing family entrepreneurial orientation. Family Business Review ,25 (2), 136-155. 


\begin{tabular}{|c|c|c|}
\hline Developmental Dimension & Stage (characteristics) & Key Challenges \\
\hline \multirow{9}{*}{$\begin{array}{c}\text { Ownership Developmental } \\
\text { Dimension (ODD) }\end{array}$} & \multirow{3}{*}{$\begin{array}{l}\text { Controlling Owner Stage (ownership control } \\
\text { consolidated in one individual or couple; } \\
\text { other owners, if any, have only token } \\
\text { holdings and do not exercise significant } \\
\text { ownership authority) }\end{array}$} & Capitalization \\
\hline & & $\begin{array}{l}\text { Balancing unitary control with input from } \\
\text { key stakeholders }\end{array}$ \\
\hline & & $\begin{array}{l}\text { Choosing an ownership structure for } \\
\text { the next generation }\end{array}$ \\
\hline & \multirow{4}{*}{$\begin{array}{l}\text { Sibling Partnership Stage (two or more } \\
\text { siblings with ownership control; effective } \\
\text { control in the hands of one sibling } \\
\text { generation) }\end{array}$} & $\begin{array}{l}\text { Developing a process for shared } \\
\text { control among owners }\end{array}$ \\
\hline & & $\begin{array}{l}\text { Defining the role of non-employed } \\
\text { owners }\end{array}$ \\
\hline & & Retaining capital \\
\hline & & $\begin{array}{l}\text { Controlling the factional orientation of } \\
\text { family branches }\end{array}$ \\
\hline & \multirow{2}{*}{$\begin{array}{l}\text { Cousin Consortium Stage (many cousin } \\
\text { shareholders; mixture of employed and } \\
\text { non-employed owners) }\end{array}$} & $\begin{array}{l}\text { Managing the complexity of the family } \\
\text { and the shareholder group }\end{array}$ \\
\hline & & $\begin{array}{l}\text { Creating a family business capital } \\
\text { market }\end{array}$ \\
\hline \multirow{9}{*}{$\begin{array}{l}\text { Business Developmental } \\
\text { Dimension (BDD) }\end{array}$} & \multirow{2}{*}{$\begin{array}{l}\text { Start-up Business (informal organizational } \\
\text { structure, with owner-manager at the center; } \\
\text { one product) }\end{array}$} & Survival \\
\hline & & Rational analysis vs the dream \\
\hline & \multirow{4}{*}{$\begin{array}{l}\text { Expansion/Formalization Business } \\
\text { (increasingly functional structure; } \\
\text { multiple products or business lines) }\end{array}$} & $\begin{array}{l}\text { Evolving the owner-manager role and } \\
\text { professionalizing the business }\end{array}$ \\
\hline & & Strategic planning \\
\hline & & Organizational systems and policies \\
\hline & & Cash management \\
\hline & \multirow{3}{*}{$\begin{array}{l}\text { Mature Business (organizational structure } \\
\text { supporting stability; stable or declining } \\
\text { customer base, with modest growth; } \\
\text { divisional structure run by senior } \\
\text { management team; well-established } \\
\text { organizational routines) }\end{array}$} & Strategic refocus \\
\hline & & $\begin{array}{l}\text { Management and ownership } \\
\text { commitment }\end{array}$ \\
\hline & & Reinvestment \\
\hline \multirow{9}{*}{$\begin{array}{l}\text { Family Developmental } \\
\text { Dimension (FDD) }\end{array}$} & \multirow{4}{*}{$\begin{array}{l}\text { Young Business Family Stage (adult } \\
\text { generation under forty; children, if any, } \\
\text { under eighteen) }\end{array}$} & $\begin{array}{l}\text { Creating a workable marriage } \\
\text { enterprise }\end{array}$ \\
\hline & & $\begin{array}{l}\text { Making initial decisions about the } \\
\text { relationship between work and family }\end{array}$ \\
\hline & & $\begin{array}{l}\text { Working out relationships with the } \\
\text { extended family }\end{array}$ \\
\hline & & Raising children \\
\hline & \multirow{3}{*}{$\begin{array}{l}\text { Entering the Business Stage (senior } \\
\text { generation between thirty-five and fifty-five; } \\
\text { junior generation in teens and twenties) }\end{array}$} & Managing the midlife transition \\
\hline & & $\begin{array}{l}\text { Separation and individuation of the } \\
\text { younger generation }\end{array}$ \\
\hline & & $\begin{array}{l}\text { Facilitating a good process for initial } \\
\text { career decisions }\end{array}$ \\
\hline & \multirow{2}{*}{$\begin{array}{l}\text { Working Together Stage (senior } \\
\text { generation between fifty and sixty-five; } \\
\text { junior generation between twenty and }\end{array}$} & $\begin{array}{l}\text { Fostering cross-generational } \\
\text { cooperation and communication }\end{array}$ \\
\hline & & Encouraging productive conflict \\
\hline
\end{tabular}




\begin{tabular}{|l|l|l|}
\hline \multirow{2}{*}{} & forty five) & management \\
\cline { 3 - 3 } & $\begin{array}{l}\text { Managing the three-generation working } \\
\text { together family }\end{array}$ \\
\cline { 2 - 3 } & $\begin{array}{l}\text { Senior generation disengagement from } \\
\text { Passing the Baton Stage (senior generation } \\
\text { the business }\end{array}$ \\
\cline { 2 - 3 } & $\begin{array}{l}\text { Generational transfer of family } \\
\text { leadership }\end{array}$ \\
\hline
\end{tabular}

Table 1. Summary of Developmental Dimensions based on Gersick et al. (1997)

Family Firm's Goals, Motivations

Family Business

Developmental Dimensions

and Preferences for

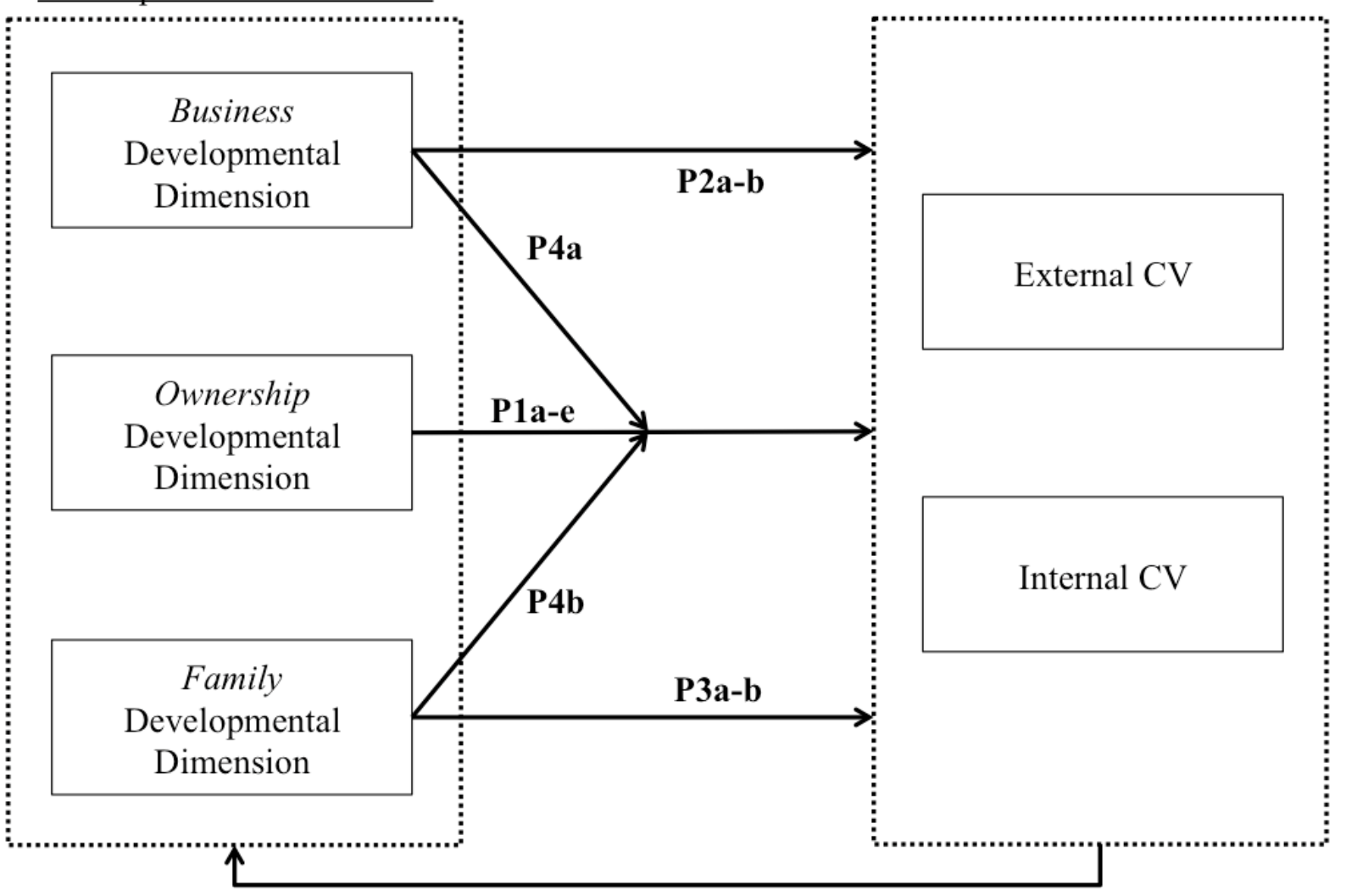

P5

Figure 1. Model of CV in family firms 